\title{
Vitamin D and Cardiovascular Disease: An Update
}

\author{
ARMIN ZITTERMANN $^{1}$ and STEFAN PILZ ${ }^{2}$ \\ ${ }^{1}$ Clinic for Thoracic and Cardiovascular Surgery, Herz- und Diabeteszentrum \\ NRW, Ruhr University Bochum, Bad Oeynhausen, Germany; \\ ${ }^{2}$ Division of Endocrinology and Diabetology, Department of Internal Medicine, \\ Medical University of Graz, Graz, Austria
}

\begin{abstract}
In the clinical setting, administration of high daily or bolus doses of vitamin $D$ is often solely based on 25hydroxyvitamin $D[25(\mathrm{OH}) D]$ testing. This review summarizes the evidence of the effect of vitamin $D$ on cardiovascular disease (CVD). Meta-analyses of randomized controlled trials (RCTs) have demonstrated that CVD risk markers, such as lipid parameters, inflammation markers, blood pressure, and arterial stiffness, are largely unaffected by vitamin $D$ supplementation. Similar results have been obtained regarding $C V D$ events and mortality from (meta)-analyses of RCTs, even in subgroups with $25(\mathrm{OH}) \mathrm{D}$ concentrations $<50 \mathrm{nmol} / \mathrm{l}$. Likewise, Mendelian randomization studies have indicated that the genetic reduction of the $25(\mathrm{OH}) \mathrm{D}$ concentration does not increase CVD risk. Some studies do not exclude the possibility of adverse vitamin D effects, such as elevated plasma calcium concentration and an increased CVD risk at a 25(OH)D concentration $>125 \mathrm{nmol} / \mathrm{l}$. Based on a conservative benefitrisk management approach, vitamin $D$ doses beyond the nutritionally recommended amounts of 600 to 800 IE daily currently cannot be advised for the prevention of CVD events.
\end{abstract}

With more than 70,000 hits available in pubmed by January 2019 , vitamin D is the vitamin with the greatest scientific interest. Moreover, the number of high-quality articles on vitamin $\mathrm{D}$, such as large prospective cohort studies or randomized controlled trials (RCTs), and meta-analyses of these types of studies steadily increased from 1993 to 2017 (Figure 1). Likewise, Mendelian randomization studies have

Correspondence to: Zittermann Armin, Ph.D., Herz- und Diabeteszentrum NRW, Clinic for Thoracic and Cardiovascular Surgery, Ruhr University of Bochum, D-32545 Bad Oeynhausen, Georgstraße 11, Germany. Tel: +49 5731971912, Fax: +49 5731972020, e-mail: azittermann@hdz-nrw.de

Key Words: Vitamin D, cardiovascular disease, meta-analysis, randomized controlled trial, Mendelian randomization study, review. shed light on the regulation of vitamin D metabolism and on health-related functions of vitamin D.

To become biologically active, vitamin $\mathrm{D}$ has to be metabolized into 1,25-dihydroxy-vitamin $\left.\mathrm{D}(1,25[\mathrm{OH}])_{2} \mathrm{D}\right)$ through two hydroxylation steps, which occur mainly in the liver (25-hydroxylase) and the kidney ( $1 \alpha$-hydroxylase) (1). Whereas 25-hydroxyvitamin D $(25[\mathrm{OH}] \mathrm{D})$ is the most abundant vitamin $\mathrm{D}$ metabolite in the circulation, $1,25(\mathrm{OH})_{2} \mathrm{D}$ is a steroid hormone, whose receptors are found in almost all tissues of the human body (1). In addition, a number of tissues are also capable of producing $1,25(\mathrm{OH})_{2} \mathrm{D}(2)$, indicating the great importance of this substance in human health and disease.

The present article is an update of a narrative review on the potential role of vitamin $\mathrm{D}$ in cardiovascular disease (CVD) (3).

\section{Search Strategy}

For this review, we performed a systematic literature search in pubmed for relevant publications released before January 31, 2019. We searched for the following terms: 'vitamin D' or 'cholecalciferol' or 'calcitriol' or '25-hydroxyvitamin D' or '1,25-dihydroxyvitamin D' combined with 'cardiovascular disease' or 'lipid parameters' or 'inflammation markers' or 'blood pressure' or 'arterial stiffness' or 'vascular calcification' or 'cardiovascular mortality' or 'all-cause mortality' or 'overall mortality'. Personal collections on this topic, as well as references from selected articles, were also used to extend the search. Some articles are not cited due to space limitations.

\section{Assessment of Vitamin D Status and its Clinical Implications Recommendations on Vitamin D Status and Intake}

Circulating $25(\mathrm{OH}) \mathrm{D}$ is generally accepted as the indicator of vitamin D status (4). Nevertheless, there is an ongoing debate on the threshold for inadequate, adequate, and potentially harmful concentrations. Several authoritative institutions such 
as North American and European nutrition societies have set the threshold for adequate $25(\mathrm{OH}) \mathrm{D}$ concentrations at $50 \mathrm{nmol} / \mathrm{l}$ (Table I) (4-7). Most of the nutrition societies suggest that the oral vitamin $\mathrm{D}$ intake required to achieve this concentration is 600 IU-800 IU daily, depending on whether low or no cutaneous vitamin D synthesis is considered. The scientific basis and rationale underlying these recommendations have been described elsewhere (4-6). Vitamin D recommendations by nutrition societies are based on bone health (4-7), whereas other organizations $(8,9)$ also take potentially non-classical vitamin D effects into consideration. These organizations argue that higher doses are necessary for the prevention of vitamin Drelated diseases $(8,9)$. They have classified 25(OH)D concentrations up to $125 \mathrm{nmol} / \mathrm{L}$ as the lower threshold for adequate $25(\mathrm{OH}) \mathrm{D}$ concentrations, and recommend an oral vitamin D intake of up to 5,000 IU vitamin D daily or more (Table I). Similar to the large disparity between some organizations and institutions regarding recommended intakes, the classification of potentially harmful 25(OH)D concentrations and the corresponding upper tolerable intake levels vary between 125 and 250-400 nmol/1, and 4,000 and 10,000 IU daily, respectively (4-10).

\section{Vitamin D Testing and Dosing}

In the clinical setting, testing of vitamin D status and recommendations on vitamin $\mathrm{D}$ supplementation are often largely based on the aforementioned measurement of circulating 25(OH)D concentrations $(11,12)$. Vitamin D supplements can be used to guarantee an adequate vitamin $\mathrm{D}$ status, i.e. $25(\mathrm{OH}) \mathrm{D}$ concentrations $>50 \mathrm{nmol} / \mathrm{l}$. However, in some European countries, such as Germany, vitamin D preparations are legally regarded as dietary supplements only if the daily dosage is within the official dietary reference intake of $800 \mathrm{IU}$ (13). Nonetheless, in cases of a 25(OH)D concentration below $50 \mathrm{nmol} / \mathrm{l}$, even higher doses (see before) or bolus doses (e.g. 50,000 IU vitamin D) are also frequently administered in the clinical setting. These highdose preparations are used for restoring, correcting, or influencing physiological functions, and/or are intended for the purpose of healing, alleviating or preventing diseases. Therefore, they formally have to be considered as drugs (13). Actually, they would require approval as a drug if vitamin D was a novel substance and not a 100-year-old known vitamin, and if diseases other than vitamin D-dependent rickets or osteomalacia should be prevented or treated.

Critique regarding vitamin $D$ blood testing. Measurement of $25(\mathrm{OH}) \mathrm{D}$ as the exclusive parameter for the assessment of vitamin D status is acceptable in large studies in the apparently healthy general population. In the clinical setting, however, caution is necessary when using this parameter as the sole criterion for assessing vitamin D status, especially if the measurement is used to recommend oral vitamin D doses much higher than 600 to 800 IU daily. Plasma $25(\mathrm{OH}) \mathrm{D}$ concentrations account for only $10 \%$ of the body's vitamin D content (14). This limits the use of this parameter in estimating vitamin D supply to its target tissues correctly. Notably, the increment in circulating $25(\mathrm{OH}) \mathrm{D}$ decreases sharply at vitamin D doses beyond 1200 IU daily (15) and circulating 25(OH)D concentrations above $100 \mathrm{nmol} / \mathrm{l}(16)$. Moreover, circulating $25(\mathrm{OH}) \mathrm{D}$ is influenced by common genetic variants in the 25-hydroxylase $(C Y P 2 R l)$ gene and the vitamin $\mathrm{D}$ binding protein gene (17). Inter-assay variability of $25(\mathrm{OH}) \mathrm{D}$ measurement is another issue, pointing to the importance of assay standardization (18), not only for the comparison of different studies with each other, but also for the correct measurement of individual 25(OH)D concentrations. Although it has been discussed whether measurement of bioactive $25(\mathrm{OH}) \mathrm{D}$ may be superior to measuring the total $25(\mathrm{OH}) \mathrm{D}$ for the vitamin $\mathrm{D}$ status assessment, there is little evidence to date for this assumption (19-21), with a potential exception in hormonal contraceptive users (22).

We should also bear in mind that the concentration of $1,25(\mathrm{OH})_{2} \mathrm{D}$, the active vitamin $\mathrm{D}$ hormone, in the circulation accounts for only 1/1000 of the concentration of its substrate $25(\mathrm{OH}) \mathrm{D}$. Because of parathyroid hormone (PTH) induces stimulation of renal $1 \alpha$-hydroxylase, even in cases of low circulating $25(\mathrm{OH}) \mathrm{D}$ concentrations, circulating $1,25(\mathrm{OH})_{2} \mathrm{D}$ concentrations remain relatively constant and become only significantly substrate-dependent at extremely low 25(OH)D concentrations (4). Although vitamin D deficiency-induced secondary hyperparathyroidism can result in bone loss (23), the effect on other organ systems, such as the cardiovascular system, is less clear. Low circulating $1,25(\mathrm{OH})_{2} \mathrm{D}$ concentrations in some diseases, such as endstage heart failure or end-stage kidney disease, should not be a priori considered to be caused by inadequate $25(\mathrm{OH}) \mathrm{D}$ availability, but may be the result of the activation of mechanisms to protect the human body from calcium and phosphate intoxication (24). Likewise, in patients with advanced heart failure and preserved kidney function, secondary hyperparathyroidism is not necessarily caused by vitamin D deficiency, but may be a disease-related compensatory effect, because PTH may also exert beneficial cardiac effects, such as increased heart rate, myocardial blood flow, and cardiac output $(25,26)$. The assessment of vitamin D status by biochemical blood parameters is further complicated by the fact that local regulation of $1,25(\mathrm{OH})_{2} \mathrm{D}$ in extra-renal tissues can be independent of substrate availability, i.e. $25(\mathrm{OH}) \mathrm{D}$ concentrations $(27,28)$. Finally, vitamin D receptor $C d x 2, F o k 1, B s m 1$, Apal, Bgll, Taq1, and Poly (A) gene polymorphisms may influence receptormediated cellular vitamin D effects (29). Altogether, the various factors that influence vitamin D metabolism make 


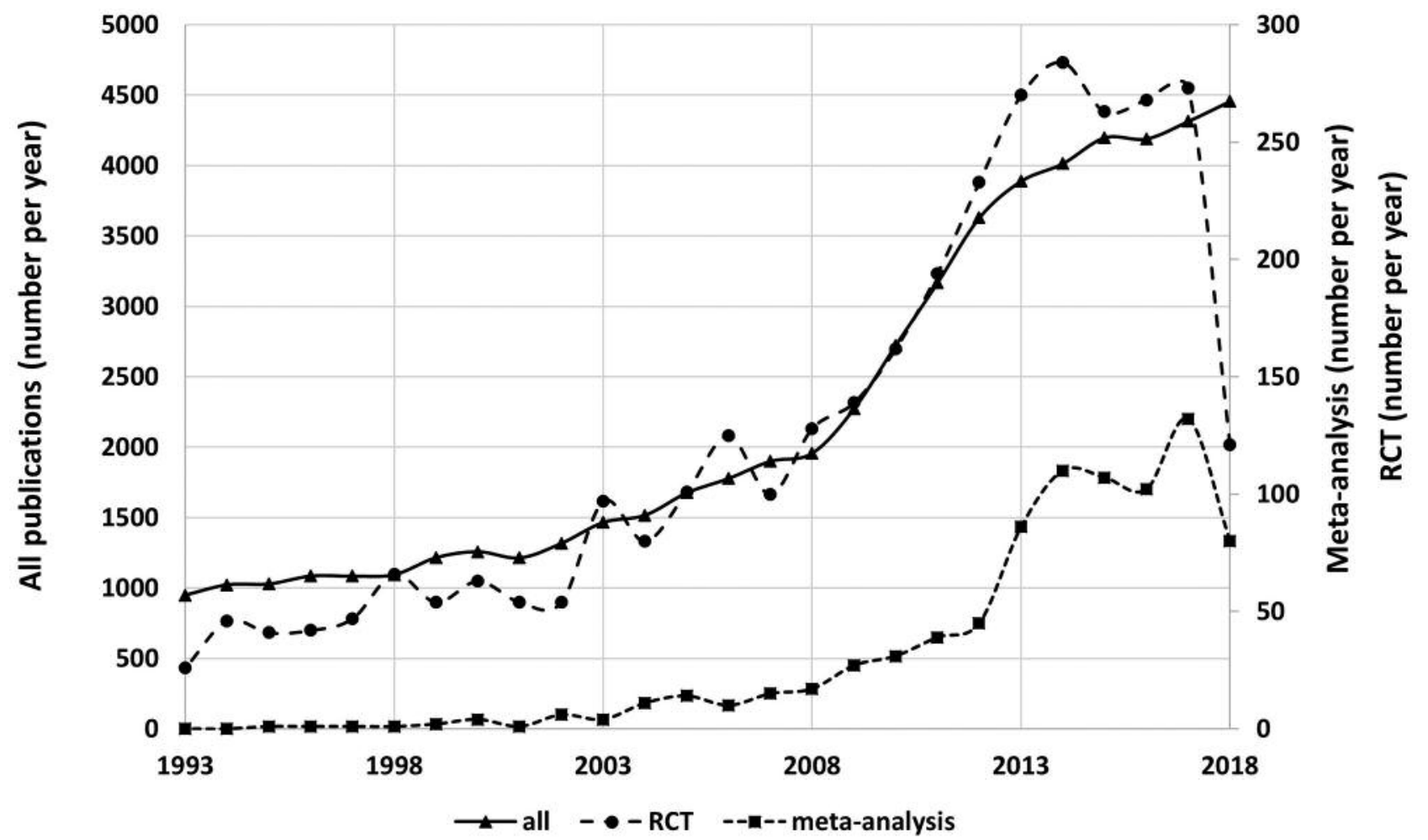

Figure 1. Pubmed-listed vitamin D publications during the last 25 years. RCT: Randomized controlled trial.

Table I. Recommended and safe circulating 25-hydroxyvitamin D concentrations, as well as daily intake values of vitamin D in adults

\begin{tabular}{|c|c|c|c|c|c|c|}
\hline & IOM & EFSA & $\mathrm{D}-\mathrm{A}-\mathrm{CH}$ & NORDEN & $\begin{array}{l}\text { Endocrine } \\
\text { society }\end{array}$ & $\begin{array}{c}\text { Vitamin D } \\
\text { Council }\end{array}$ \\
\hline Target circulating 25(OH)D (nmol/l) & 50 & 50 & 50 & 50 & 75 & $100-250$ \\
\hline Potentially harmful circulating $25(\mathrm{OH}) \mathrm{D}(\mathrm{nmol} / \mathrm{l})$ & 125 & - & - & - & 250 & $250-375$ \\
\hline Toxic circulating 25(OH)D (nmol/l) & - & - & $>400$ & - & - & $>375$ \\
\hline RDA/RI/AI, adults (IU/day) & $600-800^{\mathrm{a}}$ & 600 & 800 & $400-800^{\mathrm{a}}$ & $1,500-2,000^{\mathrm{b}}$ & $5,000^{\mathrm{c}}$ \\
\hline Upper tolerable intake level, adults (IU/day) & 4,000 & 4,000 & 4,000 & 4,000 & 10,000 & 10,000 \\
\hline
\end{tabular}

IOM: Institute of Medicine; EFSA: European Food Safety Authority; D-A-CH: Germany (D), Austria (A), Switzerland (CH); NORDEN: Nordic countries (Denmark, Iceland, Finland, Norway, Sweden); RDA: recommended dietary allowance; RI: recommended intake; AI: adequate intake; 25(OH)D: 25-hydroxyvitamin D: - not established; IU: international unit. aage-dependent recommendations; bfor obese patients 3,000-6,000 IU daily are recommended and for vitamin D deficient patients 50,000 IU vitamin D once a week for eight weeks; chigher daily doses are recommended for obese individuals; the amount is not specified, but should result in a $25(\mathrm{OH}) \mathrm{D}$ concentration around $125 \mathrm{nmol} / 1$.

health-related recommendations difficult if they are based solely on the measurement of circulating vitamin D metabolite concentrations or on associations of vitamin D metabolites with clinical outcomes. This limitation should also be considered when interpreting results of observational studies regarding CVD. Therefore, RCTs are necessary, not only to avoid the problem of unexplained confounding, but also to determine the required vitamin $\mathrm{D}$ dose and to specify the diseases in which vitamin D supplementation is useful. Ideally, RCTs should be performed in patients with vitamin $\mathrm{D}$ deficiency and well-described genetic backgrounds. In addition, they should be designed for the prevention or treatment of well-described diseases. Furthermore, they should be adequately powered to assess whether or not 
vitamin $\mathrm{D}$ is able to influence clinically relevant endpoints. Both efficacy and safety should be adequately considered.

\section{Biochemical and Clinical CVD Risk Markers}

Dyslipoproteinemia, high concentrations of pro-inflammatory cytokines, high blood pressure, and high values of parameters of arterial stiffness are considered to be risk factors for CVD. A large recent meta-analysis (30) summarized data from RCTs regarding the effect of vitamin D supplementation on lipid parameters and the inflammation marker high-sensitive Creactive protein (hs-CRP). The average vitamin $\mathrm{D}$ dose was $\sim 3,000 \mathrm{IU} /$ day; two-thirds of studies had mean baseline $25(\mathrm{OH}) \mathrm{D}$ levels $<50 \mathrm{nmol} / 1$, and the increase in circulating $25(\mathrm{OH}) \mathrm{D}$ was $48 \pm 23 \mathrm{nmol} / \mathrm{l}$. Data indicate a significant reduction in total cholesterol, LDL-cholesterol, and triglycerides of $-0.15(95 \% \mathrm{CI}=-0.25--0.04) \mathrm{mmol} / 1,-0.10(95 \% \mathrm{CI}=-0.20$ - -0.003$) \mathrm{mmol} / \mathrm{l}$, and $-0.12(95 \% \mathrm{CI}=-0.23-0.003) \mathrm{mmol} / \mathrm{l}$, respectively; an increase in HDL-cholesterol of 0.09 $(95 \% \mathrm{CI}=0.00-0.17) \mathrm{mmol} / \mathrm{l}$ and a reduction in hs-CRP of $-0.20 \quad(95 \% \mathrm{CI}=-0.34--0.06) \mathrm{mg} / \mathrm{dl}$ by vitamin $\mathrm{D}$ supplementation. There was substantial heterogeneity among studies, and subgroup analysis indicates that the vitamin D effect on triglycerides and HDL-cholesterol was higher if study participants were supplemented for $\geq 6$ months. However, there was no significant vitamin D effect according to baseline $25(\mathrm{OH}) \mathrm{D}$ concentration, daily vitamin $\mathrm{D}$ dose, or calcium co-administration on lipid parameters. Regarding hs$\mathrm{CRP}$, concentrations were marginally lower at doses $\geq 4000 \mathrm{IU}$ vitamin D/day than at doses $<4,000$ IU daily. Another metaanalysis in patients with HF (31) reported a significant suppression of the pro-inflammatory cytokine tumor necrosis factor- $\alpha$, whereas concentrations of interleukin- 6 and CRP remained unaffected. It was concluded that vitamin D supplementation may have specific, but modest effects on inflammatory markers in this group of patients. The aforementioned large meta-analysis (30) also presented data on blood pressure, and parameters of arterial stiffness, such as peak wave velocity and Augmentation Index. Data of 39 included RCTs indicate a small, but significant reduction in systolic blood pressure of $-0.102 \pm 0.04 \mathrm{mmHg}(95 \% \mathrm{CI}=-0.20--0.03)$ and diastolic blood pressure of $-0.07 \pm 0.03 \mathrm{mmHg}$ $(95 \% \mathrm{CI}=-0.14--0.006)$ by vitamin $\mathrm{D}$ supplementation. The effects were more pronounced if in-study $25(\mathrm{OH}) \mathrm{D} \geq 86 \mathrm{nmol} / 1$ were achieved, the daily vitamin $\mathrm{D}$ dose was $\geq 4,000 \mathrm{IU}$, and the duration of intervention was $\geq 6$ months, but was unaffected by baseline $25(\mathrm{OH}) \mathrm{D}$ concentration. Generally, results cover the 95\% CI of an earlier meta-analysis incorporating individual patient data from $27 \mathrm{RCTs}$, concluding that vitamin D supplementation is ineffective as an agent for lowering blood pressure (32). In that meta-analysis, the mean difference in systolic and diastolic blood pressure between individuals assigned to vitamin $\mathrm{D}$ or placebo was $-0.5(95 \% \mathrm{CI}=-1.2-0.4)$
$\mathrm{mmHg}$ and $0.2(95 \% \mathrm{CI}=-0.3-0.7) \mathrm{mmHg}$. Both meta-analyses are also in general agreement with a large Mendelian randomization study (33), indicating a non-significant reduction of $-0.37 \mathrm{mmHg}(-0.73-0.003 ; p=0.052)$ in systolic blood pressure and a significant reduction of $-0.29 \mathrm{mmHg}$ $(-0.52--0.07 ; p=0.01)$ in diastolic blood pressure with each $10 \%$ increase in genetically determined $25(\mathrm{OH}) \mathrm{D}$ concentration. With regard to arterial stiffness, the large metaanalysis by Mirhosseini et al. (30) could not show any significant effects of vitamin D supplementation, neither on pulse wave velocity, nor on Augmentation Index. Altogether, some significant but small effects of vitamin D supplementation on biochemical CVD risk markers cannot be ruled out. However, the clinical relevance of these effects is questionable, since clinical surrogate parameters of CVD risk such as blood pressure and arterial stiffness seem to be largely unaffected by vitamin D supplementation.

\section{Clinical Endpoints}

Some recent meta-analyses have summarized data from RCTs regarding the effect of vitamin D supplementation on CVD outcomes (34-36). Data indicate that vitamin D supplementation influences neither non-fatal CVD events, such as the risk of myocardial infarction, stroke or ischemic heart disease, nor the risk of CVD deaths. However, these meta-analyses were primarily based on studies in which CVD outcomes were only secondary endpoints. Therefore, the results of two recent very large vitamin D supplementation studies in the elderly general population are important: In a New Zealand study (37), 5,110 communityresident adults aged 50 to 84 years were assigned to a monthly vitamin D bolus of 100,000 IU vitamin D or placebo for a mean duration of 3.34 years. The primary endpoint was incident CVD and death, including a prespecified subgroup analysis in participants with baseline $25(\mathrm{OH}) \mathrm{D}$ concentrations $<50 \mathrm{nmol} / \mathrm{l}$. In a nationwide US study (38), 25,871 men 50 years of age or older and women 55 years of age or older received 2,000 IU vitamin D daily, marine n-3 fatty acids or placebo by a two-by-two factorial design for a median duration of 5.3 years. The primary endpoint was a composite of myocardial infarction, stroke, or death from cardiovascular causes. In the New Zealand study (37), the incidence of the primary endpoint was reached by $11.8 \%$ in the vitamin D group and $11.5 \%$ in the placebo group, yielding an adjusted hazard ratio of 1.02 (95\% CI $=0.87-1.20)$. Similar results were seen for participants with baseline vitamin D levels $<50 \mathrm{nmol} / \mathrm{l}$ and for secondary endpoints such as myocardial infarction, angina, heart failure, hypertension, arrhythmias, arteriosclerosis, stroke, and venous thrombosis. In the US study (38), the hazard ratio of the primary endpoint was for the vitamin D versus the placebo group $0.97(95 \% \mathrm{CI}=0.85$ - 
1.12). Likewise, the hazard ratio did not differ significantly between the study groups for an expanded composite of major cardiovascular events plus coronary revascularization and the individual components of major cardiovascular events. Moreover, subgroup analysis did not indicate an interaction of age, sex, race, body mass index or baseline $25(\mathrm{OH}) \mathrm{D}$ level $(<50 \mathrm{nmol} / \mathrm{l}$ and $\geq 50 \mathrm{nmol} / \mathrm{l})$ with the study group with regard to major CVD events. In both aforementioned RCTs, the prevalence of $25(\mathrm{OH}) \mathrm{D}$ levels classified by the IOM as deficient $(<30 \mathrm{nmol} / \mathrm{l})(4)$, was not explicitly specified, but was apparently very low. Results published by a European consortium of eight prospective studies using individual patient data and standardized $25(\mathrm{OH}) \mathrm{D}$ values indicate the highest CVD mortality at 25(OH)D levels less than $30 \mathrm{nmol} / 1$ (39). Likewise, a large meta-analysis of cohort studies (40) reported a sharp nonlinear increase in the risk of CVD events and CVD mortality at $25(\mathrm{OH}) \mathrm{D}$ concentrations below $37 \mathrm{nmol} / \mathrm{l}$. A beneficial vitamin D effect on CVD risk can thus at best be expected in individuals with baseline $25(\mathrm{OH}) \mathrm{D}$ concentrations within the deficiency range, i.e. $<30 \mathrm{nmol} / 1$. In line with this assumption, vitamin D supplementation was not associated with a reduction in CVD events in a very recent metaanalysis of RCTs in individuals not selected for initial 25(OH)D levels below $30 \mathrm{nmol} / \mathrm{l}(41)$.

In line with the results of the RCTs, large Mendelian randomization studies indicate that genetically lowered 25(OH)D levels are not associated with increased risk of coronary artery disease (CAD) or myocardial infarction (42, $43)$. Genetically enhanced $25(\mathrm{OH}) \mathrm{D}$ levels of $20 \mathrm{nmol} / \mathrm{l}$ were more likely to be associated with a marginally higher risk of CVD mortality (odds ratio $=1.30 ; 95 \% \mathrm{CI}=0.93-1.82$ ) (44). However, results were obtained in the clinical setting and may reflect the association between $25(\mathrm{OH}) \mathrm{D}$ and disease progression, rather than disease occurrence. With respect to the associations between the polymorphisms of vitamin D receptor and CAD, two meta-analyses $(45,46)$ provided inconsistent results. Whereas one meta-analysis (45) concluded that the Apa 1, Fok 1, Taq 1, and Bsm 1 polymorphisms of the $V D R$ gene may not be associated with genetic susceptibility to CAD, the other meta-analysis (46) concluded that the Fok 1 polymorphism may play a protective role in CAD and the Taq 1 polymorphism is associated with a significant increase in CAD risk. The analysis by Alizadeh et al. (45) was based on nine studies involving a total of 5,259 cases and 1,981 controls, and the analysis by $\mathrm{Lu}$ et al. (46) was based on seven studies involving 2,306 CAD patients and 4,151 controls.

\section{Overdosing of Vitamin D and CVD}

In the two aforementioned large population-based RCTs (37, 38 ), the incidence of hypercalcemia, which is the hallmark of vitamin D intoxication, did not differ between participants assigned to vitamin $\mathrm{D}$ or placebo, and there was no evidence for adverse vitamin D effects on the cardiovascular system. In the New Zealand and US studies, mean in-study 25(OH)D concentrations in the participants with available $25(\mathrm{OH}) \mathrm{D}$ data were $132 \mathrm{nmol} / 1$ and $104 \mathrm{nmol} / \mathrm{l}$, respectively. Moreover, a large meta-analysis of cohort studies by Zhang et al. (40) did not provide evidence regarding the adverse effects of 25(OH)D levels between 100 and $137 \mathrm{nmol} / 1$ on CVD events in the general population. However, data should not be generalized to all groups of individuals. Some large cohort studies from the clinical setting indicate an increase in CVD events at 25(OH)D levels above $100 \mathrm{nmol} / \mathrm{l}(47-49)$. In an RCT in patients with advanced heart failure (50), a daily vitamin D3 supplement of 4,000 IU for 3 years resulted in a greater need for mechanical circulatory support implants. In end-stage heart failure patients, the devices are implanted as last option to prevent death. The need of device implantation was highest in the subgroup of patients achieving in-study 25(OH)D levels above $100 \mathrm{nmol} / 1$. Compared to placebo, vitamin $\mathrm{D}$ also resulted in significantly higher plasma calcium levels and a nonsignificant higher incidence of hypercalcemia (6.2\% vs. $3.1 \%$ ). Vitamin D-induced hypercalcemia has been associated with vascular calcification $(51,52)$ and mild hypercalcemia had been reported in $28 \%(\mathrm{n}=213)$ and $2 \%$ $(n=12)$ of infants at 6 and 12 months, respectively, during daily vitamin D supplementation of 400 or 1,200 IU (53). The infants with mild hypercalcemia at 12 months of age had an average $25(\mathrm{OH}) \mathrm{D}$ concentration of $110 \mathrm{nmol} / \mathrm{l}$. A recent meta-analysis regarding long-term ( $\geq 1$ year), high dose (median of the calculated daily dose: 4,000 IU) vitamin $\mathrm{D}$ supplementation and hypercalcemia events reported a risk ratio of $1.93(95 \% \mathrm{CI}=1.00-3.73 ; p=0.05)$ in the vitamin D group vs. the placebo group (54). The clinical relevance of the slight increase in plasma calcium levels at physiological daily vitamin D doses is unknown at present. However, higher plasma calcium levels are nonlinearly associated with an increased incidence of heart failure (55). Since the evidence for beneficial vitamin D effects on CVD risk is lacking, caution regarding vitamin D supplementation is necessary. In nutritional science, a conservative benefit-risk management approach is proposed for food components: only convincing evidence should be taken into account for beneficial effects, but also probable and possible evidence for adverse effects (56). Therefore, circulating 25(OH)D levels of 100 to $125 \mathrm{nmol} / 1$ should not be exceeded. In some adults, 4,000 IU vitamin D daily may already be too high to avoid 25(OH)D levels $>100 \mathrm{nmol} / 1$ (50). Thus, the approach to legally regard vitamin D preparations as dietary supplements only if the daily dosage is within the official dietary reference intake of $800 \mathrm{IU}$ (13), seems to make sense. 


\section{Conclusion}

Experimental studies have shown that animals lacking vitamin $\mathrm{D}$ action, induced either by deletion of the vitamin $\mathrm{D}$ receptor or by vitamin D-depleted diets, develop vascular calcification and atherosclerosis $(57,58)$. However, available data from large prospective cohort studies and RCTs indicate that no beneficial vitamin $\mathrm{D}$ effects on the cardiovascular system can be expected in individuals with $25(\mathrm{OH}) \mathrm{D}$ levels above $30 \mathrm{nmol} / 1$. In the adult US and European populations, the prevalence of circulating $25(\mathrm{OH}) \mathrm{D}$ concentrations below $30 \mathrm{nmol} / 1$ is $8 \%$ and $13 \%$, respectively $(59,60)$. Potential future studies regarding vitamin D and CVD risk should focus on this group of individuals. However, the time window for these studies is closing since food fortification with vitamin D has already been introduced in some countries and is recommended for other countries as a safe and cost-effective strategy for preventing deficient $25(\mathrm{OH}) \mathrm{D}$ levels (61).

Until food fortification with vitamin D is implemented in the general population, a nutritional supplement of 600 to 800 IU vitamin $\mathrm{D}$ daily can be used to prevent a decrease in circulating 25(OH)D concentrations below $30 \mathrm{nmol} / 1$ if skin synthesis of vitamin D is low or absent. However, convincing evidence for reducing the risk of CVD by vitamin D supplementation is lacking.

\section{Conflicts of Interest}

The Authors have no conflicts of interest to declare regarding this study.

\section{Authors' Contributions}

AZ and SP both contributed to the concept and design of the work. AZ drafted the manuscript. SP critically reviewed it for its intellectual content. Both Authors approved the final version of the article.

\section{References}

1 Zittermann A: Vitamin D in preventive medicine: are we ignoring the evidence? Br J Nutr 89: 552-572, 2003. PMID: 12720576. DOI: $10.1079 / \mathrm{BJN} 2003837$

2 Zittermann A and Gummert JF: Nonclassical vitamin D action. Nutrients 2: 408-425, 2010. PMID: 22254030. DOI: 10.3390/ nu2040408

3 Zittermann A: Vitamin D status, supplementation and cardiovascular disease. Anticancer Res 38: 1179-1186, 2018. PMID: 29374756. DOI: 10.21873 /anticanres.12338

4 Institute of Medicine. Dietary reference intakes: calcium and vitamin D. Washington, DC: National Academies Press, 2011. DOI: $10.17226 / 13050$.

5 EFSA NDA Panel (EFSA Panel on Dietetic Products, Nutrition and Allergies) (2016) Scientific opinion on dietary reference values for vitamin D. EFSA J 14: 4547, 2016.DOI: 10.2903/j.efsa.2016.NNN.

6 DGE (German Nutrition Society), Österreichische Gesellschaft für Ernährung, Schweizerische Gesellschaft für Ernährungsforschung,
Schweizerische Vereinigung für Ernährung (2012) D-A-CHReferenzwerte für die Nährstoffzufuhr, 1. Auflage, 5., korrigierter Nachdruck 2013, Neuer Umschau Buchverlag, Neustadt an der Weinstraße.

7 Nordic Council of Ministers 2014. Nordic Nutrition Recommendations 2012. 5th edition, Narayana Press. DOI: 10.6027/Nord2014-002.

8 Holick MF, Binkley NC, Bischoff-Ferrari HA, Gordon CM, Hanley DA, Heaney RP, Murad MH and Weaver CM: Endocrine Society: Evaluation, treatment, and prevention of vitamin D deficiency: An Endocrine Society clinical practice guideline. J Clin Endocrinol Metab 96: 1911-1930, 2011. PMID: 21646368. DOI: $10.1210 /$ jc.2011-0385

9 Vitamin D Council. For health professionals: Position statement on supplementation, blood levels and sun exposure. https://www.vitamindcouncil.org/for-health-professionalsposition-statement-on-supplementation-blood-levels-and-sunexposure/\#.XGFmyuTsaAg. Accessed on January 31th, 2019.

10 EFSA Panel on Dietetic Products, Nutrition and Allergies (NDA) (2012) Scientific opinion on the tolerable upper intake level of vitamin D. EFSA J 10: 2813, 2012. DOI: 10.2903/j.efsa.2012.2813

11 Sattar N, Welsh P, Panarelli M and Forouhi NG: Increasing requests for vitamin D measurement: costly, confusing, and without credibility. Lancet 379: 95-96, 2012. PMID: 22243814. DOI: $10.1016 /$ S0140-6736(11)61816-3

12 Pilz S, Zittermann A, Trummer C, Theiler-Schwetz V, Lerchbaum E, Keppel MH, Grübler MR, März W and Pandis M: Vitamin D testing and treatment: a narrative review of current evidence. Endocr Connect 8: R27-R43, 2019. PMID: 30650061. DOI: $10.1530 / \mathrm{EC}-18-0432$

13 Gemeinsame Expertenkommission zur Einstufung von Stoffen. Stellungnahme zu Vitamin-D-haltigen Produkten (01/2016) Revision 1.1 (2017). Bundesinstitut für Arzneimittel und Medizinprodukte. https://www.bfarm.de/SharedDocs/Downloads/ DE/Arzneimittel/Zulassung/ZulRelThemen/abgrenzung/Expertenk ommission/stellungnahmen/2016-01-Rev1_1.html, accessed February 5th, 2019.

14 Heaney RP, Horst RL, Cullen DM and Armas LA: Vitamin D3 distribution and status in the body. J Am Coll Nutr 28: 252-256, 2009. PMID: 20150598. DOI: 10.1080/07315724.2009. 10719779

15 Aloia JF, Patel M, Dimaano R, Li-Ng M, Talwar SA, Mikhail M, Pollack S and Yeh JK: Vitamin D intake to attain a desired serum 25-hydroxyvitamin D concentration. Am J Clin Nutr 87: 1952-1958, 2008. PMID: 18541590. DOI: 10.1093/ajcn/ 87.6.1952

16 Heaney RP, Armas LA, Shary JR, Bell NH, Binkley N and Hollis BW: 25-Hydroxylation of vitamin D3: relation to circulating vitamin D3 under various input conditions. Am J Clin Nutr 87: 1738-1742, 2008. PMID: 18541563. DOI: 10.1093/ ajcn/87.6.1738

17 Nissen J, Vogel U, Ravn-Haren G, Andersen EW, Madsen KH, Nexø BA, Andersen R, Mejborn H, Bjerrum PJ, Rasmussen LB and Wulf HC: Common variants in CYP2R1 and GC genes are both determinants of serum 25-hydroxyvitamin $\mathrm{D}$ concentrations after UVB irradiation and after consumption of vitamin $D_{3^{-}}$ fortified bread and milk during winter in Denmark. Am J Clin Nutr 101: 218-227, 2015. PMID: 25527766. DOI: 10.3945/ ajcn.114.092148 
18 Durazo-Arvizu RA, Tian L, Brooks SPJ, Sarafin K, Cashman KD, Kiely M, Merkel J, Myers GL, Coates PM and Sempos CT: The Vitamin D Standardization Program (VDSP) Manual for Retrospective Laboratory Standardization of Serum 25Hydroxyvitamin D Data. J AOAC Int 100: 1234-1243, 2017. PMID: 28718397. DOI: 10.5740/jaoacint.17-0196

19 Schwartz JB, Lai J, Lizaola B, Kane L, Weyland P, Terrault NA, Stotland N and Bikle D: Variability in free $25(\mathrm{OH})$ vitamin D levels in clinical populations. J Steroid Biochem Mol Biol 144: 156-158, 2013. PMID: 24240067. DOI: 10.1016/j.jsbmb. 2013.11.006

20 Martucci G, Tuzzolino F, Arcadipane A, Pieber TR, Schnedl C, Urbanic Purkart T, Treiber G and Amrein K: The effect of highdose cholecalciferol on bioavailable vitamin D levels in critically ill patients: a post hoc analysis of the VITdAL-ICU trial. Intensive Care Med 43: 1732-1734, 2017.PMID: 28550402. DOI: $10.1007 / \mathrm{s} 00134-017-4846-5$

21 Thambiah SC, Wong TH, Gupta ED, Radhakrishnan AK, Gun SC, Chembalingam G, Lai LC and Yeap SS: Calculation of free and bioavailable vitamin $\mathrm{D}$ and its association with bone mineral density in Malaysian women. Malays J Pathol 40: 287-294, 2018. PMID: 30580359.

22 Pilz S, Obeid R, Schwetz V, Trummer C, Pandis M, Lerchbaum E, Pieber TR, Obermayer-Pietsch B, Wilhelm M, Hahn A and Schön C: Hormonal contraceptive use is associated with higher total but unaltered free 25-hydroxyvitamin D serum concentrations. J Clin Endocrinol Metab 103: 2385-2391, 2018 PMID: 29672719. DOI: $10.1210 /$ jc.2018-00336

23 Lips P: Vitamin D deficiency and secondary hyperparathyroidism in the elderly: consequences for bone loss and fractures and therapeutic implications. Endocr Rev 22: 477-501, 2001. PMID: 11493580. DOI: 10.1210/edrv.22.4.0437

24 Zittermann A and Ernst JB: Calciotropic and phosphaturic hormones in heart failure. Nutr Metab Cardiovasc Dis 26: 971-979, 2016. PMID: 27493144. DOI: 10.1016/j.numecd.2016.06.007

25 Zittermann A, Ernst JB, Prokop S, Fuchs U, Dreier J, Kuhn J, Berthold HK, Pilz S, Gouni-Berthold I and Gummert JF: Vitamin D supplementation and bone turnover in advanced heart failure: the EVITA trial. Osteoporos Int 29: 579-586, 2018. PMID: 29260292. DOI: 10.1007/s00198-017-4312-9

26 Ogino K, Burkhoff D and Bilezikian JP: The hemodynamic basis for the cardiac effects of parathyroid hormone (PTH) and PTHrelated protein. Endocrinology 136: 3024-3030, 1995. PMID: 7789328. DOI: $10.1210 /$ endo.136.7.7789328

27 Liu PT, Stenger S, Li H, Wenzel L, Tan BH, Krutzik SR, Ochoa MT, Schauber J, Wu K, Meinken C, Kamen DL, Wagner M, Bals R, Steinmeyer A, Zügel U, Gallo RL, Eisenberg D, Hewison M, Hollis BW, Adams JS, Bloom BR and Modlin RL: Toll-like receptor triggering of a vitamin D-mediated human antimicrobial response. Science 311: 1770-1773, 2006.PMID: 16497887. DOI: $10.1126 /$ science. 1123933

28 Schauber J, Dorschner RA, Coda AB, Büchau AS, Liu PT, Kiken D, Helfrich YR, Kang S, Elalieh HZ, Steinmeyer A, Zügel U, Bikle DD, Modlin RL and Gallo RL: Injury enhances TLR2 function and antimicrobial peptide expression through a vitamin D-dependent mechanism. J Clin Invest 117: 803-811, 2007. PMID: 17290304 . DOI: $10.1172 / \mathrm{JCI} 30142$

29 Iqbal MUN and Khan TA: Association between Vitamin D receptor (Cdx2, Fok1, Bsm1, Apa1, Bgl1, Taq1, and Poly (A)) gene polymorphism and breast cancer: A systematic review and meta-analysis. Tumour Biol 39: 1010428317731280, 2017. PMID: 29072133. DOI: 10.1177/1010428317731280

30 Mirhosseini N, Rainsbury J and Kimball SM: Vitamin D Supplementation, Serum 25(OH)D Concentrations and Cardiovascular Disease Risk Factors: A Systematic Review and Meta-Analysis. Front Cardiovasc Med 5: 87, 2018. PMID: 30050908. DOI: 10.3389/fcvm.2018.00087

31 Rodriguez AJ, Mousa A, Ebeling PR, Scott D and de Courten B: Effects of vitamin D supplementation on inflammatory markers in heart failure: a systematic review and meta-analysis of randomized controlled trials. Sci Rep 8: 1169, 2018. PMID: 29348609. DOI: $10.1038 / \mathrm{s} 41598-018-19708-0$

32 Beveridge LA, Struthers AD, Khan F, Jorde R, Scragg R, Macdonald HM, Alvarez JA, Boxer RS, Dalbeni A, Gepner AD, Isbel NM, Larsen T, Nagpal J, Petchey WG, Stricker H, Strobel F, Tangpricha V, Toxqui L, Vaquero MP, Wamberg L, Zittermann A, Witham MD and D-PRESSURE Collaboration: Effect of Vitamin D Supplementation on Blood Pressure: A Systematic Review and Meta-analysis Incorporating Individual Patient Data. JAMA Intern Med 175: 745-754, 2015. PMID: 25775274. DOI: 10.1001/jamainternmed.2015.0237

33 Vimaleswaran KS, Cavadino A and Berry DJ; LifeLines Cohort Study investigators, Jorde R, Dieffenbach AK, Lu C, Alves AC, Heerspink HJ, Tikkanen E, Eriksson J, Wong A, Mangino M, Jablonski KA, Nolte IM, Houston DK, Ahluwalia TS, van der Most PJ, Pasko D, Zgaga L, Thiering E, Vitart V, Fraser RM, Huffman JE, de Boer RA, Schöttker B, Saum KU, McCarthy MI, Dupuis J, Herzig KH, Sebert S, Pouta A, Laitinen J, Kleber ME, Navis G, Lorentzon M, Jameson K, Arden N, Cooper JA, Acharya J, Hardy R, Raitakari O, Ripatti S, Billings LK, Lahti J, Osmond C, Penninx BW, Rejnmark L, Lohman KK, Paternoster L, Stolk RP, Hernandez DG, Byberg L, Hagström E, Melhus H, Ingelsson E, Mellström D, Ljunggren O, Tzoulaki I, McLachlan S, Theodoratou E, Tiesler CM, Jula A, Navarro P, Wright AF, Polasek O; International Consortium for Blood Pressure (ICBP); Cohorts for Heart and Aging Research in Genomic Epidemiology (CHARGE) consortium; Global Blood Pressure Genetics (Global BPGen) consortium; Caroline Hayward, Wilson JF, Rudan I, Salomaa V, Heinrich J, Campbell H, Price JF, Karlsson M, Lind L, Michaëlsson K, Bandinelli S, Frayling TM, Hartman CA, Sørensen TI, Kritchevsky SB, Langdahl BL, Eriksson JG, Florez JC, Spector TD, Lehtimäki T, Kuh D, Humphries SE, Cooper C, Ohlsson C, März W, de Borst MH, Kumari M, Kivimaki M, Wang TJ, Power C, Brenner H, Grimnes G, van der Harst P, Snieder H, Hingorani AD, Pilz S, Whittaker JC, Järvelin MR and Hyppönen E: Association of vitamin D status with arterial blood pressure and hypertension risk: a mendelian randomisation study. Lancet Diabetes Endocrinol 2: 719-729, 2014. PMID: 24974252. DOI: $10.1016 /$ S2213-8587(14)70113-5

34 Elamin MB, Abu Elnour NO, Elamin KB, Fatourechi MM, Alkatib AA, Almandoz JP, Liu H, Lane MA, Mullan RJ, Hazem A, Erwin PJ, Hensrud DD, Murad MH and Montori VM: Vitamin D and cardiovascular outcomes: a systematic review and meta-analysis. J Clin Endocrinol Metab 96: 1931-1942, 2011. PMID: 21677037. DOI: 10.1210/jc.2011-0398

35 Bolland MJ, Grey A, Gamble GD and Reid IR: The effect of vitamin D supplementation on skeletal, vascular, or cancer outcomes: a trial sequential meta-analysis. Lancet Diabetes Endocrinol 2: 307-320, 2014. PMID: 24703049. DOI: 10.1016/ S2213-8587(13)70212-2 
36 Jenkins DJA, Spence JD, Giovannucci EL, Kim YI, Josse R, Vieth R, Blanco Mejia S, Viguiliouk E, Nishi S, SahyePudaruth S, Paquette M, Patel D, Mitchell S, Kavanagh M, Tsirakis T, Bachiri L, Maran A, Umatheva N, McKay T, Trinidad G, Bernstein D, Chowdhury A, Correa-Betanzo J, Del Principe G, Hajizadeh A, Jayaraman R, Jenkins A, Jenkins W, Kalaichandran R, Kirupaharan G, Manisekaran P, Qutta T, Shahid R, Silver A, Villegas C, White J, Kendall CWC, Pichika SC and Sievenpiper JL: Supplemental Vitamins and Minerals for CVD Prevention and Treatment. J Am Coll Cardiol 71: 2570-2584, 2018. PMID: 29852980. DOI: $10.1016 /$ j.jacc.2018.04.020

37 Scragg R, Stewart AW, Waayer D, Lawes CMM, Toop L, Sluyter J, Murphy J, Khaw KT and Camargo CA Jr: Effect of monthly high-dose vitamin D supplementation on cardiovascular disease in the vitamin D assessment study: A randomized clinical trial. JAMA Cardiol 2: 608-616, 2017. PMID: 28384800. DOI: 10.1001/jamacardio.2017.0175

38 Manson JE, Cook NR, Lee IM, Christen W, Bassuk SS, Mora S, Gibson H, Gordon D, Copeland T, D'Agostino D, Friedenberg G, Ridge C, Bubes V, Giovannucci EL, Willett WC, Buring JE and VITAL Research Group: Vitamin D Supplements and Prevention of Cancer and Cardiovascular Disease. N Engl J Med 380: 33-44, 2019. PMID: 30415629. DOI: $10.1056 /$ NEJMoa1809944

39 Gaksch M, Jorde R, Grimnes G, Joakimsen R, Schirmer H, Wilsgaard T, Mathiesen EB, Njølstad I, Løchen ML, März W, Kleber ME, Tomaschitz A, Grübler M, Eiriksdottir G, Gudmundsson EF, Harris TB, Cotch MF, Aspelund T, Gudnason V, Rutters F, Beulens JW, van't Riet E, Nijpels G, Dekker JM, Grove-Laugesen D, Rejnmark L, Busch MA, Mensink GB, Scheidt-Nave C, Thamm M, Swart KM, Brouwer IA, Lips P, van Schoor NM, Sempos CT, Durazo-Arvizu RA, Škrabáková Z, Dowling KG, Cashman KD, Kiely M and Pilz S: Vitamin D and mortality: Individual participant data meta-analysis of standardized 25-hydroxyvitamin D in 26916 individuals from a European consortium. PLoS One 12: e0170791, 2017. PMID: 28207791. DOI: 10.1371/journal.pone.0170791

40 Zhang R, Li B, Gao X, Tian R, Pan Y, Jiang Y, Gu H, Wang Y, Wang Y and Liu G: Serum 25-hydroxyvitamin D and the risk of cardiovascular disease: dose-response meta-analysis of prospective studies. Am J Clin Nutr 105: 810-819, 2017. PMID: 28251933. DOI: $10.3945 /$ ajcn.116.140392

41 Barbarawi M, Kheiri B, Zayed Y, Barbarawi O, Dhillon H, Swaid B, Yelangi A, Sundus S, Bachuwa G, Alkotob ML and Manson JE: Vitamin D supplementation and cardiovascular disease risks in more than 83000 individuals in 21 randomized clinical trials: A meta-analysis. JAMA Cardiol, 2019. PMID: 31215980. DOI: $10.1001 /$ jamacardio.2019.1870

42 Brøndum-Jacobsen P, Benn M, Afzal S and Nordestgaard BG: No evidence that genetically reduced 25 -hydroxyvitamin $D$ is associated with increased risk of ischaemic heart disease or myocardial infarction: a Mendelian randomization study. Int J Epidemiol 44: 651-661, 2015. PMID: 25981321. DOI: 10.1093/ije/dyv078

43 Manousaki D, Mokry LE, Ross S, Goltzman D and Richards JB: Mendelian Randomization Studies Do Not Support a Role for Vitamin D in Coronary Artery Disease. Circ Cardiovasc Genet 9: 349-356, 2016. PMID: 27418593. DOI: 10.1161/CIRC GENETICS.116.001396
44 Afzal S, Brøndum-Jacobsen P, Bojesen SE and Nordestgaard BG: Genetically low vitamin D concentrations and increased mortality: Mendelian randomisation analysis in three large cohorts. BMJ 349: g6330, 2014. PMID: 25406188. DOI: 10.1136/bmj.g6330

45 Alizadeh S, Djafarian K, Alizadeh H, Mohseni R and Shab-Bidar S: Common variants of Vitamin D receptor gene polymorphisms and susceptibility to coronary artery disease: a systematic review and meta-analysis. J Nutrigenet Nutrigenomics 10: 9-18, 2017. PMID: 28351026. DOI: 10.1159/000455914

46 Lu S, Guo S, Hu F, Guo Y, Yan L, Ma W, Wang Y, Wei Y, Zhang $\mathrm{Z}$ and Wang $\mathrm{Z}$ : The Associations Between the Polymorphisms of Vitamin D Receptor and Coronary Artery Disease: A Systematic Review and Meta-Analysis. Medicine (Baltimore). 95: e3467, 2016. PMID: 27227912. DOI: 10.1097/MD.0000000000003467

47 Dror Y, Giveon SM, Hoshen M, Feldhamer I, Balicer RD and Feldman BS: Vitamin D levels for preventing acute coronary syndrome and mortality: evidence of a nonlinear association. J Clin Endocrinol Metab 98: 2160-2167, 2013. PMID: 23533239. DOI: 10.1210/jc.2013-1185

48 Durup D, Jørgensen HL, Christensen J, Tjønneland A, Olsen A, Halkjær J, Lind B, Heegaard AM and Schwarz P: A Reverse JShaped Association Between Serum 25-Hydroxyvitamin D and Cardiovascular Disease Mortality: The CopD Study. J Clin Endocrinol Metab 100: 2339-2346, 2015. PMID: 25710567. DOI: 10.1210/jc.2014-4551

49 Zittermann A, Kuhn J, Dreier J, Knabbe C, Gummert JF and Börgermann J: Vitamin D status and the risk of major adverse cardiac and cerebrovascular events in cardiac surgery. Eur Heart J 34: 13581364, 2013. PMID: 23315905. DOI: 10.1093/ eurheartj/ehs468

50 Zittermann A, Ernst JB, Prokop S, Fuchs U, Dreier J, Kuhn J, Knabbe C, Birschmann I, Schulz U, Berthold HK, Pilz S, GouniBerthold I, Gummert JF, Dittrich M and Börgermann J: Effect of vitamin D on all-cause mortality in heart failure (EVITA): a 3 -year randomized clinical trial with $4000 \mathrm{IU}$ vitamin D daily. Eur Heart J 38: 2279-2286, 2017. PMID: 28498942. DOI: 10.1093 / eurheartj/ehx235

51 Zittermann A and Koerfer R: Protective and toxic effects of vitamin D on vascular calcification: clinical implications. Mol Aspects Med 29: 423-432, 2008. PMID: 18538838. DOI: 10.1016/j.mam.2008.04.002

52 Zittermann A, Prokop S, Gummert JF and Börgermann J: Safety issues of vitamin D supplementation. Anticancer Agents Med Chem 13: 4-10, 2013. PMID: 23094916. DOI: 10.2174/ 1871520611307010004

53 Valkama S, Holmlund-Suila E, Enlund-Cerullo M, Rosendahl J, Hauta-Alus H, Helve O, Hytinantti T, Viljakainen H, Andersson S and Mäkitie O: No severe hypercalcemia with daily vitamin D3 supplementation of up to $30 \mu \mathrm{g}$ during the first year of life. Horm Res Paediatr 88: 147-154, 2017. PMID: 28647736. DOI: $10.1159 / 000477298$

54 Malihi Z, Wu Z, Lawes CMM and Scragg R: Adverse events from large dose vitamin $\mathrm{D}$ supplementation taken for one year or longer. J Steroid Biochem Mol Biol 188: 29-37, 2019. PMID: 30529281. DOI: $10.1016 /$ j.jsbmb.2018.12.002

55 Lutsey PL, Alonso A, Michos ED, Loehr LR, Astor BC, Coresh J and Folsom AR: Serum magnesium, phosphorus, and calcium are associated with risk of incident heart failure: The Atherosclerosis Risk in Communities (ARIC) Study. Am J Clin Nutr. 100: 756764, 2014. PMID: 25030784. DOI: 10.3945/ ajen.114.085167 
56 Boobis A, Chiodini A, Hoekstra J, Lagiou P, Przyrembel H, Schlatter J, Schütte K, Verhagen H and Watzl B: Critical appraisal of the assessment of benefits and risks for foods, 'BRAFO Consensus Working Group'. Food Chem Toxicol 55: 659-675, 2013. PMID: 23123424. DOI: 10.1016/j.fct.2012. 10.028

57 Schmidt N, Brandsch C, Kühne H, Thiele A, Hirche F and Stangl GI: Vitamin D receptor deficiency and low vitamin D diet stimulate aortic calcification and osteogenic key factor expression in mice. PLoS One 7: e35316, 2012. PMID: 2253 6373. DOI: 10.1371/journal.pone.0035316

58 Schmidt N, Brandsch C, Schutkowski A, Hirche F and Stangl GI: Dietary vitamin D inadequacy accelerates calcification and osteoblast-like cell formation in the vascular system of LDL receptor knockout and wild-type mice. J Nutr 144: 638-646, 2014. PMID: 24647396. DOI: 10.3945/jn.113.189118

59 Looker AC, Johnson CL, Lacher DA, Pfeiffer CM, Schleicher RL and Sempos CT: Vitamin D status: United States, 2001-2006. NCHS Data Brief 59: 1-8, 2011. PMID: 21592422.

60 Cashman KD, Dowling KG, Škrabáková Z, Gonzalez-Gross M, Valtueña J, De Henauw S, Moreno L, Damsgaard CT, Michaelsen KF, Mølgaard C, Jorde R, Grimnes G, Moschonis G, Mavrogianni C, Manios Y, Thamm M, Mensink GB, Rabenberg M, Busch MA, Cox L, Meadows S, Goldberg G, Prentice A, Dekker JM, Nijpels
G, Pilz S, Swart KM, van Schoor NM, Lips P, Eiriksdottir G, Gudnason V, Cotch MF, Koskinen S, Lamberg-Allardt C, DurazoArvizu RA, Sempos CT and Kiely M: Vitamin D deficiency in Europe: pandemic? Am J Clin Nutr 103: 1033-1044, 2016. PMID: 26864360. DOI: 10.3945/ajcn.115.120873

61 Pilz S, März W, Cashman KD, Kiely ME, Whiting SJ, Holick MF, Grant WB, Pludowski P, Hiligsmann M, Trummer C, Schwetz V, Lerchbaum E, Pandis M, Tomaschitz A, Grübler MR, Gaksch M, Verheyen N, Hollis BW, Rejnmark L, Karras SN, Hahn A, Bischoff-Ferrari HA, Reichrath J, Jorde R, Elmadfa I, Vieth R, Scragg R, Calvo MS, van Schoor NM, Bouillon R, Lips P, Itkonen ST, Martineau AR, Lamberg-Allardt $\mathrm{C}$ and Zittermann A: Rationale and Plan for Vitamin D Food Fortification: A Review and Guidance Paper. Front Endocrinol (Lausanne) 9: 373, 2018. PMID: 30065699. DOI: 10.3389/fendo.2018.00373

Received June 18, 2019

Revised July 2, 2019

Accepted July 3, 2019 